\title{
Assessment of the Sustainability of Public Housing Projects in Ogun State, Nigeria: A Post Occupancy Evaluation Approach
}

\author{
Eziyi O. Ibem ${ }^{1}$ \\ Egidario. B.Aduwo ${ }^{2}$ \\ 182 Department of Architecture, College of Science and Technology, Covenant University, \\ KM 10 Idiroko Road, Canaan Land, Ota, Ogun State, Nigeria \\ 1 Email Address: ibem.eziyi@covenantuniversity.edu.ng \\ 2 Email Address: egidario.aduwo@covenantuniversity.edu.ng
}

\section{Emmanuel K. Ayo-Vaughan}

Department of Architecture, College of Environmental Sciences, Bells University of Technology, Ota, Ogun State, Nigeria Email Address: kunlevaughan@gmail.com

Doi:10.5901/mjss.2015.v6n4s2p523

\section{Abstract}

As the emphasis on sustainability increases among architects and construction professionals, the various ways for achieving sustainability in physical development projects have continued to engage the attention of scholars and researchers across the globe. However, in the context of housing in a developing country like Nigeria, there is a paucity of empirical studies on the sustainability of public housing projects. Therefore, this study aimed at identifying and analyzing the sustainability features of public housing projects in urban areas of Ogun State, Nigeria. A survey of 517 residents in nine public housing estates was conducted between December 2009 and February 2010 in the study area. With the aid of structured questionnaire, interview guide and observation schedule; data were collected and analyzed using descriptive statistics and content analyses. Findings show that public housing projects in the study area were evaluated to be sustainable in terms of affordability and building forms responding to site and climatic conditions. The projects were however found to be unsustainable in the use of asbestos-based materials, inadequate provision of domestic spaces and lack of basic social infrastructural facilities. The paper concludes that to achieve sustainability in public housing in Nigeria, there is a need for public housing developers to pay adequate attention to users' domestic space and basic social infrastructural facilities need in the design, construction and management of housing projects.

Keywords: Public Housing; Sustainability; Housing Characteristics; Survey; Ogun State; Nigeria

\section{Introduction}

The need for public housing schemes to meet some basic sustainability parameters has continued to be of concern to housing policy makers, developers, experts, and researchers across the world. Savaya et al. (2008) explained that since 1987 when the World Commission of Environment and Development Report brought to the fore the issues of sustainable development, experts involved in the design and implementation if social programmes have been exploring strategies for achieving sustainability in such schemes. In the context of housing, Chiu (2003:224) noted that until all the sustainability aspects of housing are adequately researched and integrated, it would not be possible to seek a sustainable development path for housing".

Although the concept of sustainability has been a subject of debate in the literature, there appears to be a consensus in the literature that sustainability generally refers to the ability of a society, ecosystem, or any other system, projects/programme, to continue functioning optimally throughout its life span without being forced to decline on account of exhaustion of vital resources (Ghani, 2012). Bond et al. (2012) also noted that the concept of sustainability is normative and cannot be singularly or categorically defined, and thus what constitutes sustainability in the context of an individual sustainability assessment needs to be determined on a case-by-case basis. These authors defined sustainability assessment as one aspect of impact assessment that places emphasis on delivering positive net sustainability gains now and into the future (Bond et al., 2012). 
Regarding housing development, the published literature (Chiu, 2003; Abdellatif et al., 2006; Odebiyi, 2010; Turcotte, and Geiser, 2010; Ihuah et al., 2014) reveals that sustainability has become a vital issue in the conception, development and management of housing projects. In Nigeria, although attempts have been made in the past to explore the outcomes of public housing schemes from the perspectives of residents' satisfaction (see for examples Jiboye, 2009; Clement and Kayode, 2012; Ibem and Amole, 2013), accessibility to basic services and social infrastructure (Ibem, 2013), the physical conditions (UN-HABITAT, 2006) and housing affordability (Mbamali and Okoli, 2002; Oruwari, 2006); Ihuah et al. (2014) however noted that the concern for sustainability of housing projects is still in its infancy in this country. This suggests that there is a limited research on the sustainability of public housing projects in Nigeria.

It is against this background that this study aimed at examining the sustainability of public housing projects constructed between 2003 and 2010 in Ogun State Southwest Nigeria. The key objectives were to identify and analyse the characteristics of public housing in Ogun State, Nigeria; and the extent to which the features alignment with sustainable housing initiatives. To achieve these objectives the study sought to address two research questions. These are:

i. What are the characteristics of public housing constructed in Ogun State between 2003 and 2010; and

ii. To what extent do these characteristics align with sustainable housing initiatives?

The data used in this paper were taken from a research project conducted to investigate public housing in Ogun State, Nigeria. The choice of Ogun State for this research was due to the number of housing projects developed by government in the State in the last ten years. The study contributes to improving our understanding of the sustainability features of recently constructed public housing in the study area. Also findings of this study is expected to be a valuable addition to the current discourse on sustainable housing development; and serve as feedback to policy makers and housing developers in Nigeria.

\section{Literature Review}

\subsection{The concept of sustainable housing initiatives}

The existing literature (Omole, 2001; Zami and Lee, 2010) shows that the concept of housing has been understood from three perspectives; namely, as a physical structure (house) and commodity that has both social and economic values; physical structure and neighbourhood environment; and as a process through which residential buildings and associated infrastructural services are provided. It was on this premise that the National Housing Policy of Nigeria (2012) noted that "housing in all its ramifications, is more than mere shelter, since it embraces all the social services and utilities that go to make a community or neighborhood a liveable environment (p4)". This means that sustainable housing encompasses housing product, services and processes.

Ihuah et al. (2014) were of the view that although there were several conceptions and definitions of sustainable housing initiatives in the existing literature, there was still a need to explore and understand the vital features of sustainable housing. This was corroborated by Franks (2006) who noted that the understanding of what constitutes sustainable and unsustainable initiatives is critical to assessing the success of projects and/or programmmes. From the works of Mitlin and Satterthwaite (1996) we understand that sustainable housing describes "shelter that is healthy, safe, affordable and secure within a neighbourhood with provision of piped water, sanitation, drainage, transport, healthcare, education and child development. It is also a home protected from environmental hazards, including chemical pollution. Also important are to meet needs related to people's choice and control, including homes and neighbours which they value and where their social and cultural priorities are met (p31-32)". This conception is concerned with mainly housing products and associated services. The EU also viewed sustainable housing in terms of the quality of construction, social and economic factors such as affordability, and psychological impacts, and eco-efficiency (VROM, 2005). Hence, Choguill (2007) identified economic viability; social acceptability, technical visibility and environmental compatibility as the key features of sustainable housing initiatives. Several other authors (e.g. Lutzkendorf and Lorenz, 2005; Abdellatif and Othman, 2006; Winston, 2007; Odebiyi, 2010) have also emphasized economic; social and environmental dimensions of sustainable development as the parameters for assessing sustainable housing initiatives. These descriptions are very insightful as they capture the three key aspects of housing as previously highlighted.

The existing literature also indicates that sustainable housing initiatives can be discussed at four different levels. These are the individual buildings (where design for security, comfort, good indoor air and sense of identity (Ghani, 2012; Ibem et al., 2013), energy efficiency of buildings (Menzies and Wherrette, 2005; Mitterer et al., 2012); building form in relation to the site, region, climate and available materials (Ghani, 2012) are examined. Second is the immediate environment where such issues as the presence and/or absence of sources of potential safety threats, the level of social 
functionality, crowding, exposure to noise and the design and layout of external spaces are investigated (Bonnefoy, 2007). There is also the neighbourhood environment that entails the measurement of accessibility to amenities such as open spaces and parking areas by residents (Ibem 2013). Lastly is the community level where public perceptions of positive and negative impacts of housing schemes on the immediate community in particular and society at large is the main concern (Hashim, 2004)

It can be inferred from the foregoing that the economic, social and environmental aspects of sustainable development are vital considerations in describing sustainable housing process, products and services at dwelling unit, immediate and neighbourhood environment and community levels. In the current study, the focus is on the housing unit; immediate environment and neigbhourhood levels; meaning that the aspects related to housing process and community level assessment of sustainability are outside the scope of this study.

\subsection{Sustainability assessment of public housing projects}

The term "sustainability" was first conceptualized in the World Commission of Environment and Development Report (1987) in which sustainable development was defined as the development that meets the needs of the present generation without compromising the ability of future generations to meet their needs (WCED, 1987). Based on this definition, authors have put forward different conceptions of sustainability as explained by Marcause (1998) and Rotmans (2006). Marcause (1998) specifically noted that on the one hand, the concept of sustainability has come as a reminder to all generations to conduct every activity on the planet earth with the highest degree of caution by making it sustainable. On the other hand, Chiu (2000) argued that although sustainability has environmental origin, it generally connotes a concern for social and economic equity between generations and seeks to deliver human settlements that enhance the quality of life and satisfaction of people by promoting efficient use of resources. Furthermore, sustainability has also been described as a concept that deals with the need to achieve and sustain economic, social and environmental benefits in all human endeavours (Lee and Chan, 2010). Based on these definitions, Ibem and Azuh (2011) concluded that sustainability is concerned with the need to ensure that in every human endeavour, basic social, economic and environmental needs of the present generation are met without compromising the potential of the posterity to meet their needs.

From the foregoing, it is obvious that sustainability deals with the protection, improvement and sustenance of a good quality of life and environment in such a way that present generation can meet its needs without jeopardizing the chances of posterity in meeting their needs. Put succinctly, sustainability helps to recognize that there is a need for developments that maintain a balance between human activities and the environment. Hence, in the context of this study, sustainability is used to describe the extent to which public housing projects are considered to be suitable in meeting the housing needs and expectations of residents with little or no adverse social, economic and environmental consequences.

On how sustainability can be measured, Sadler (1999) was of the view that sustainability assessment is the third generation of impact assessment, following environmental impact assessment (EIA) and strategic environmental assessment (SEA). Hacking and Guthrie (2008) noted that sustainability assessment is a generic term describing a range of impact assessment practice which helps to classify the characteristics of projects, programmes and processes and the extent to which they contribute to sustainability. Bond et al. (2012) identified environmental, social and health impact assessments as examples of sustainability assessments. These authors further claimed that a majority of the existing published works on sustainability assessments relate to very specific, one-off, case studies rather than general practice or conceptual studies in the different fields.

Although many tools and techniques are available to support sustainability assessment processes, Bond et al. (2012) explained that the majority of the existing analytical tools and techniques are mitigation biased with focus on avoidance and minimization of adverse impacts. For physical development projects, studies (Dalal-Clyton and Sadler; 2004; Turcotte and Geiser, 2010) have shown that the existing sustainability assessment techniques and models are environmentally biased; and this may be due to the environmental origin of sustainable development. From the review of literature we found some examples of sustainability assessment models to include: cost-benefit analysis (CBA) (Ekins and Vanner 2007); sustainability oriented multi- criteria analysis (MCA) (Kain and So"derberg 2008); life cycle assessment, indicators and scenario planning (Ness et al. 2007). Some authors (Bebbington et al., 2007; Turcotte and Geiser, 2010; Ibem and Azuh 2011) have criticized these models as not being comprehensive enough; and thus advocated for the adoption of holistic sustainability assessment models that incorporate social, economic and environmental aspects of sustainability. One of the approaches identified as capable of addressing the three aspects of sustainability when it comes to assessment of the sustainability of buildings and other constructed facilities at post construction phase is post occupancy evaluation (POE). According to Ornstein (2005), POE is a set of methods and 
techniques applied during use of the built environment to evaluate building and environment performance from the perspectives of specialists and that of the users. It measures among other things the social, economic and environmental performance of the built environment (Ibem et al., 2012); and thus provides feedback to policy makers; services providers, administrators and managers for decision making as explained by Ornstein (2005).

A number of sustainability assessment studies have been carried out using the POE approach. For instance, Blair et al. (2004) used 37 variables drawn from economic (e.g. affordability); social (sense of community; neighbourhood safety and satisfaction; transportation) and environmental constructs (environment-biodiversity; environment-energy; environment- resources consciousness; environment-wastewater/storm water control) to assess the sustainability of communities. Pullen, et al. (2010) developed and tested an assessment framework for affordable and sustainable housing in Australia by using ten variables related to economic sustainability (affordability), social sustainability (quality of life; quality of place and health) and environmental sustainability (energy efficiency; construction materials; construction methods). Similarly, Turcotte and Geiser (2010) have also put forward a sustainability assessment framework for physical development projects comprising social sustainability (healthy internal environment, safety, provision of social amenity, provision of recreation amenity and accessibility to jobs and amenities)(ii) economic sustainability (cost efficiency over time, affordability, job creations and local economy), (iii) environmental sustainability (energy efficiency, water conservation, reduction of greenhouse gas emissions, waste management, material efficiency, pollution prevention, optimization and conservation of land, protection and enhancement of biodiversity, reduction of dependency on car); and (iv) cultural sustainability (designing housing that preserves, respects, and recognizes the unique historical and cultural characteristics of an area and its residents). Turcotte and Geiser's (2010) framework appears to be the most comprehensive of all identified here; and as such some of its elements were used in the current study.

From the review of literature, it can be inferred that sustainability assessment is one of the tools for measuring the extent to which products, processes and programmes/projects contribute to sustainability. It is also evident that the ultimate goal of sustainability assessment of housing projects is to investigate and understand the extent to which housing features align with the social, economic and environmental needs of the residents and communities.

From the findings of the review of literature, a conceptual framework of the study was developed. The components of this framework are graphically illustrated in Figure 1.

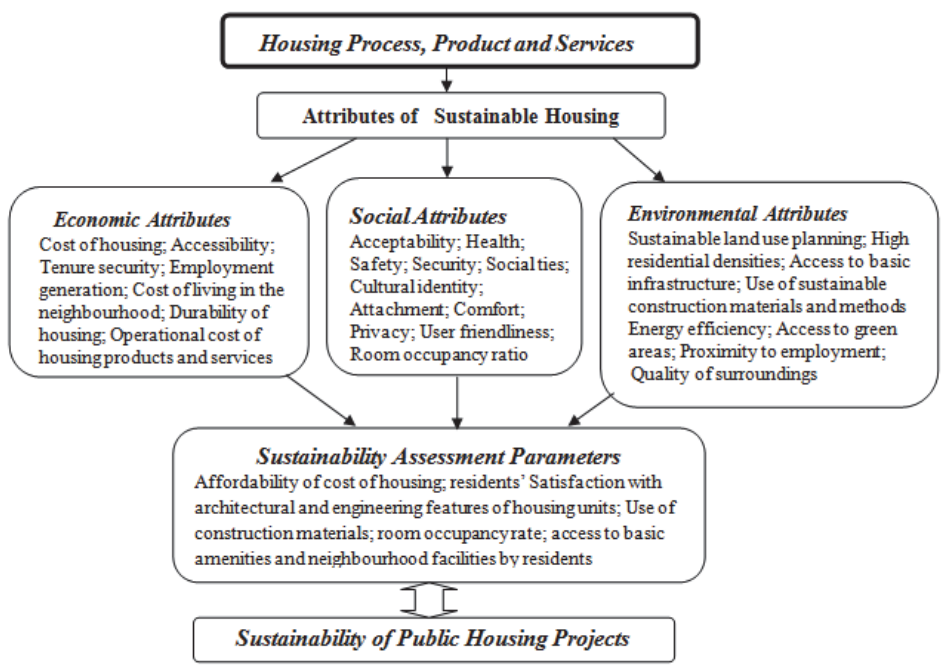

Figure 1: Conceptual Framework of the Study

Figure 1 shows that the attributes of sustainable housing process, products and services can be described based on the economic, social and environmental aspects of sustainable development. Therefore, the basic underlying assumption of this framework is that there is a direct relationship between the characteristics of sustainable housing (e.g. affordability; social acceptability and quality of environment in housing estates and others) and the sustainability of housing projects. To this end, housing affordability (economic aspect); residents' satisfaction with architectural and engineering 
characteristics of housing units; room occupancy rate (socio-cultural aspects), the use of construction materials; access to basic amenities and neighbourhood facilities by residents (environmental aspect) were used as parameters for assessing the sustainability of public housing projects in the current study.

\section{Research Methods}

As stated earlier, the goal of this study was to examine the sustainability of public housing constructed between 2003 and 2010 in Ogun State, Nigeria, using selected social, economic and environmental parameters as shown in Figure 1. To achieve this goal, the survey research approach was used due to the nature of the research questions; and the advantages it has in allowing researchers to generate both quantitative and qualitative data that describe trends, attitudes or opinions of a population on specific issues by studying a sample of that population as explained by Creswell (2009). The data reported in this paper were collected from the residents of public housing in the study area. Specifically, household surveys were conducted in nine of the twelve public housing estates constructed between 2003 and 2010 in urban areas of Ogun State to obtain data from housing occupants. Housing estates sampled were OGD-Workers Housing Estate, Laderin; Media Village, OGD Housing Estate, Asero; Presidential Mandate Housing Estate, Olokota and Obasanjo Hill-Top GRA Housing Estate all in Abeokuta; OGD Housing Estate Itanrin, ljebu-Ode; and OPIC Housing Estate, Agbara. Others were the OSHC Housing Estate, Ota and OGD-Sparklight Housing Estate in Ibafo.

Two instruments assisted the researchers in the data collection process. The first was structured questionnaire administered to residents of housing estates sampled in this study. The questionnaire comprised three sections. Section 1 was used to gather data on the socio-economic characteristics (e.g. sex, age, education, income, marital status, and tenure status) of the respondents. Section 2 had questions on the spatial characteristics of housing such as the size of dwelling units and type of toilet facilities, sources of utilities as well as additional space requirements in their dwelling units. Residents were also asked questions on their satisfaction level with the quality of day lighting and natural ventilation in main activities areas of the houses such as living-dining, and bedroom; privacy, thermal comfort; and the materials used in the construction of the houses based on 5-Likert type scale ranging from "1" for "Very Dissatisfied" to 5 for Very Satisfied. Section 3 of the questionnaire elicited responses from the residents on economic characteristics of housing (e.g. affordability of the cost of housing) based on 5-Likert type scale of 'Highly Unaffordable', 'Unaffordable', 'Not Sure'; 'Affordable' and 'Highly Affordable'.

The second data gathering instrument used was observation schedule. This instrument did not contain questions, rather it was used to record observations made with respect to the physical characteristics of the housing units and housing estate sampled. The aforementioned data collection instruments were complimented by photographic materials and sketch pads. It is noteworthy that all the questions chosen for the survey were designed based on findings from the review of literature; and were pre-tested before they were administered to the target population. This was to ensure that the questions were suitable for the target population in the housing estates.

The surveys were conducted between December 2009 and February 2010. At the time of the surveys, a total of 1,523 housing units were built in the aforementioned housing estates, but $709(47 \%)$ of the houses were occupied by residents. The remaining 814 housing units were yet to be occupied. As a result, the stratified sampling technique was used to select 670 housing units representing about $95 \%$ of the occupied housing units for the research. This sampling technique was adopted in order to have a sample size representing low, middle, and high-income households from the different housing estates. A total of 670 questionnaires were administered. One questionnaire was given by hand to one adult member found in each household in the housing units visited by the researchers and four research assistants who assisted in the data collection process. However, 517 valid questionnaires representing approximately $77 \%$ of the distributed questionnaires were retrieved.

The data derived from the questionnaire and observation schedule were analyzed using descriptive statistics (frequencies and percentages). These were used in computing the proportion and percentages of the respondents' in the different socio-economic groups; housing types and sizes; and residents' perception of the affordability of the cost of housing in the nine estates.

\section{Result}

\subsection{Personal profile of the Respondents}

Table 1 shows personal profiles of all the 517 respondents drawn from the housing units in the nine housing estates sampled. Examination of data in Table 1 reveals that $64 \%$ of the respondents were males, while $36 \%$ were females, $57 \%$ 
were between 31years and 45years and 96\% were highly educated. Table 1 also shows that $63 \%$ of the respondents were classified as low-income earners and owner-occupiers; and around $71 \%$ of the respondents had household size of four persons and above. This result indicates that residents encountered in the survey are mainly educated males of middle-aged group and low-income earners living in owner-occupied housing units.

Table 1: Profiles of the Respondents

\begin{tabular}{ccc}
\hline & $\mathrm{n}=517$ & Percentage \\
\hline Respondent's Sex & & \\
Male & 333 & 64.4 \\
Female & 184 & 35.6 \\
Age Group in Years & 3 & 0.6 \\
No Response & 65 & 12.6 \\
$18-30$ & 293 & 56.7 \\
$31-45$ & 140 & 27.1 \\
$46-59$ & 16 & 3.1 \\
60 and above & & \\
No Response & 8 & 1.6 \\
Primary Education & 4 & 0.8 \\
Secondary Education & 11 & 2.1 \\
Tertiary Education & 494 & 95.6 \\
*Average Monthly Income (Naira) & & \\
No Response & 36 & 7.0 \\
Below N38,000 (Low-Income) & 137 & 26.5 \\
Highest Educational Attainment & 186 & 36.0 \\
N38,000-N71,000 (Middle Low Income) & 77 & 15.0 \\
N72,000-N145,000 (Middle High Income) & 81 & 15.7 \\
N145,000 and above (High Income) & & \\
Tenure Type & 3 & 0.6 \\
No Response & 168 & 32.5 \\
Privately Rented & 323 & 62.4 \\
Owner Occupied & 23 & 4.5 \\
Official Quarters & &
\end{tabular}

*1US\$= N203 as at April 2015

Source: Authors' Field Work (2010)

\subsection{Characteristics of housing units in the estates}

The result reveals that of the 517 housing units sampled, $62 \%$ were walk-in homes ( i.e. houses ready for occupation), $37 \%$ were starter/core houses (one-bedroom housing units that can later be expanded to 3-bedrooms by the occupants) and around $2 \%$ were shell houses (houses constructed without finishes, doors and windows and sanitary facilities and sold by the developers to interested members of the public who are expected put the finishes and facilities according to their taste). Figure 2 shows the sizes of the dwelling units sampled. It is evident from Figure 2 that about $42 \%$ and $36 \%$ of the housing units were 3-bedroom and 2-bedroom units, respectively. The above result clearly shows that in the nine public housing estates sampled, a majority of the dwelling units are walk-in homes consisting of 2-and 3-bedroom bungalows.

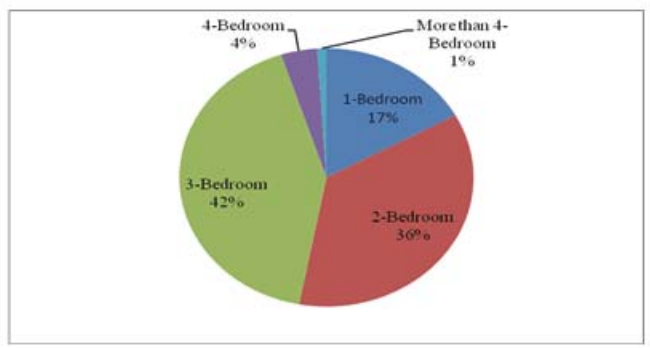

Figure 2: Sizes of Dwelling Units

Source: Authors' Field Work (2010) 
Also around $52 \%$ of houses sampled were found to be single family bungalows, $46 \%$ were semi-detached starter houses (see Figure 3) and 3\% were residential buildings of two floors occupied by one household (maisonettes).

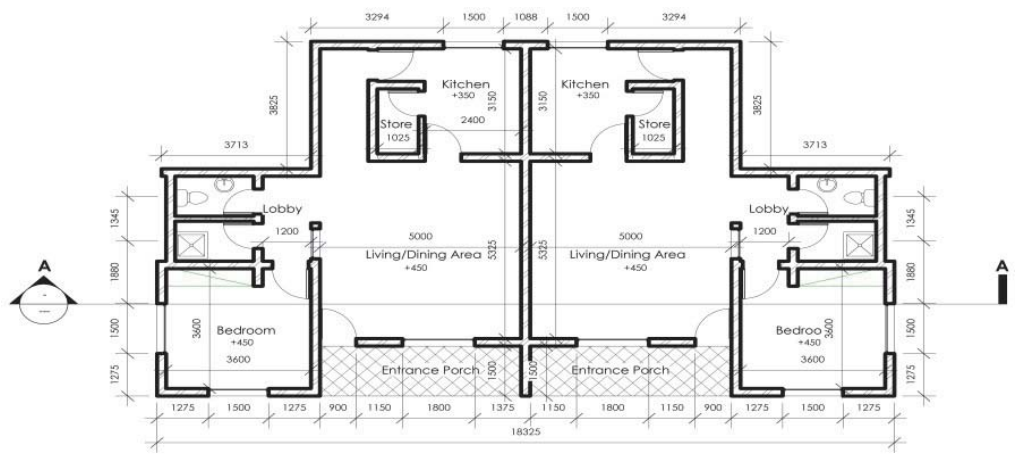

Figure 3: Floor Plan of Semi-detached Starter Houses

Source: Authors' Field Work (2010)

It was observed that the floor plans of the houses were mainly of regular geometric forms of squares and rectangles that respond to site conditions and with good internal spatial arrangement as shown in Figure 2. The plans of the dwelling units also indicate that adequate consideration was given to security of lives and property of the residents in the design and construction of the houses as seen in clear demarcation of spaces using walls (i.e. closed plan system) and limited number of external doors. Windows were also provided to enhance day lighting, ventilation and thermal comfort of the occupants.

The residents were asked to rate their levels of satisfaction with security, quality of natural lighting and ventilation in living-dining areas and bedrooms. The result reveals that $95 \%$ of the respondents expressed satisfaction with the level of security of lives and property within and around their residences. The result (Table 2) also shows that 95\% were satisfied, while only $6 \%$ were dissatisfied with the quality of natural lighting and ventilation in the interior spaces. It is also evident from Table 2 that a majority of those sampled were happy with the levels of security, thermal comfort, privacy, natural lighting and ventilation in their dwelling units.

Table 2: Satisfaction with natural lighting, ventilation, thermal comfort and privacy in the housing units

\begin{tabular}{|c|c|c|c|c|c|}
\hline No Response & Very Dissatisfied & Dissatisfied & Neutral & Satisfied & Very Satisfied \\
\hline \multicolumn{6}{|c|}{ Natural Lighting and ventilation in Living-Dining } \\
\hline $0(0)$ & $2(.4)$ & $27(5.2)$ & 148(28.6) & $313(60.5)$ & $27(5.2)$ \\
\hline \multicolumn{6}{|c|}{ Natural Lighting and ventilation in Kitchen } \\
\hline $4(.8)$ & $5(1.0)$ & $17(3.3)$ & $177(34.2)$ & $259(50.1)$ & $55(10.6)$ \\
\hline \multicolumn{6}{|c|}{ Natural ventilation bedrooms } \\
\hline $4(.8)$ & $2(0.4)$ & $12(2.3)$ & $215(41.6)$ & $241(46.6)$ & $43(8.3)$ \\
\hline \multicolumn{6}{|c|}{ Natural Lighting in bedrooms } \\
\hline $2(0.4)$ & $5(1.0)$ & $13(2.5)$ & $195(37.7)$ & $263(50.9)$ & $39(7.5)$ \\
\hline \multicolumn{6}{|c|}{ Thermal comfort in the residence } \\
\hline $17(3.3)$ & $5(1.0)$ & $18(3.5)$ & 140(27.1) & $314(60.7)$ & $23(4.4)$ \\
\hline \multicolumn{6}{|c|}{ Level of privacy in the residence } \\
\hline $4(0.8)$ & $5(1.0)$ & $10(1.9)$ & $104(20.1)$ & $294(56.9)$ & $100(19.3)$ \\
\hline
\end{tabular}

Source: Authors' Field Work (2010)

The respondents were also asked to indentify space(s) not provided in their current dwelling units that they would like to have. The result is a presented in Table 3. 
Table 3: Desired amenities by respondents in the Housing Units

\begin{tabular}{lcc}
\hline Spaces & Frequency & Percentage \\
\hline No additional requirement & 61 & 11.8 \\
Shop and Laundry & 50 & 9.7 \\
Shop and Storage spaces only & 53 & 10.3 \\
Shop and Visitors toilet & 52 & 10.1 \\
Shop and Guest Room & 47 & 9.1 \\
Outdoor Cooking area & 15 & 2.9 \\
Guest Room , Visitors Toilet and Laundry & 239 & 42.2 \\
\hline
\end{tabular}

Source: Authors' Field Work (2010)

From Table 3, it is evident that around $12 \%$ of the respondents had no desired amenities in their homes; suggesting that spaces in their dwelling units are adequate in meeting their current needs. However, around $42 \%$ of the respondents made request for additional spaces such as guest room, visitors' toilet and laundry space; suggesting that these are the desired amenities lacking in the their current residences. In fact, the highest proportion of those who desired guest facilities lived in 2-bedrooms (28\%), followed by $27 \%$ of those in 3-bedroom apartments and $19 \%$ of those in 1-bedroom housing units. Interestingly, $10 \%$ of low-income and $3 \%$ of middle-low income earners desired to have space for shops in their current dwelling units.

Regarding room occupancy rate, the result also shows that close to $25 \%$ of housing units in the nine estates sampled had room occupancy rate of 0.6 person per room, $15 \%$ had 0.5 person, $14 \%$ had 1 person and $11 \%$ had 0.75 person per room. This result indicates that the average occupancy rate in the houses sampled was 0.6; suggesting that room occupancy ratio is less than one person per room in most of the houses in the estates. It can be inferred from this result that the housing units sampled were not overcrowded at the time the surveys.

\subsection{The use of materials in housing construction}

Result of the analysis shows that most of the houses sampled were constructed with conventional building materials. Specifically, $96 \%$ of the houses were constructed with Sandcrete cement blocks (see Figure 4), while only $4 \%$ were built with burnt bricks. Also all the houses were roofed with aluminium long span roofing sheets and had glazed aluminium windows, while very few had glazed louvered windows. Similarly, around $59 \%$ of houses sampled had paneled steel external doors and $40 \%$. Around $94 \%$ of houses sampled had asbestos ceiling, while the remaining percentage were of acoustic ceiling and PVC strips. Also around $53 \%$ of houses in the nine estates sampled had perimeter fencing with iron gates (see Figure 4). It was also observed that around $98 \%$ of the houses had steel burglary proof windows. The result shows that $77 \%$ of respondents were satisfied with the type of materials used in the construction of the buildings in the nine housing estates investigated; meaning that a majority of them are happy with the types of materials used in the construction of their houses.

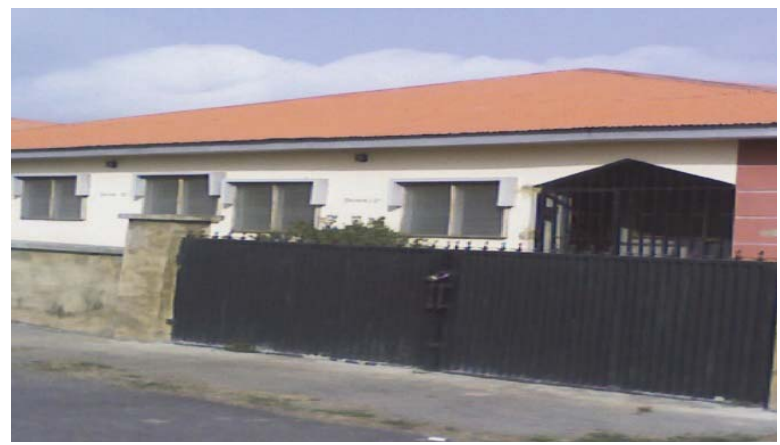

Figure 4: External appearance of a typical housing unit

Source: Authors' Field Work (2010) 


\subsection{Characteristics of the Housing estates}

Table 4 presents the summary of the key features of the nine housing estates investigated. It is evident from Table 4 that all the housing estates had parking spaces, street lights and are connected to the public power supply system ( see also Figure 5); while $78 \%$ of the estates had asphalt paved roads, shopping facilities and places of worship.

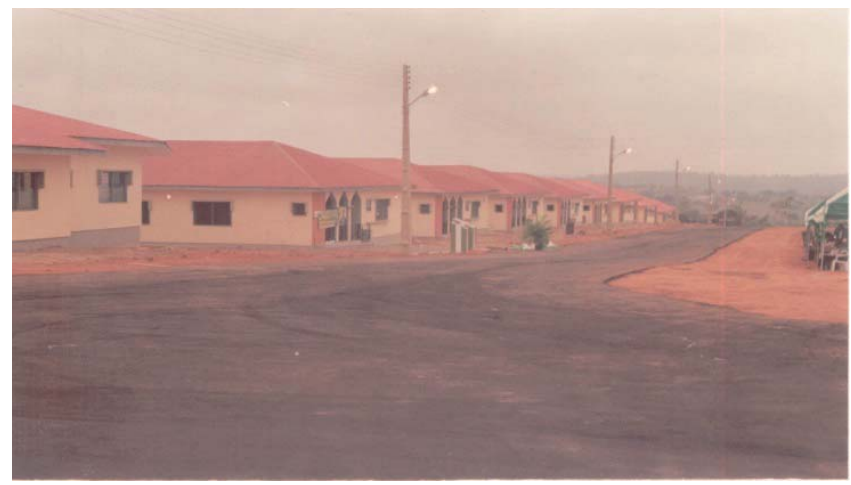

Figure 5: Pictorial view of the buildings, paved road and street lighting in one of the Housing Estates Source: Authors' Field Work (2010)

Notably, only one of the nine housing estates had a functional healthcare facility, while none of them had pedestrian walkways and recreational/sporting facilities. Table 4 also shows that the housing estates were highly deficient in facilities for children such as schools and planned outdoor play areas. Consequently, a majority of the respondents expressed dissatisfaction with the closeness of their homes to public infrastructure and urban services.

Table 4: Characteristics of the Housing Estates

\begin{tabular}{ll}
\hline Features/Facilities & $\mathbf{n}=\mathbf{9}$ \\
\hline Characteristics of roads in the Estates & 7 of the 9 housing estates had asphalt paved roads \\
Pedestrian Walkways Present & Non-existence in all the estates \\
Security Post at the entrances & Available in 5 housing estates \\
Police Post & Available in 2 housing estates \\
Shopping Facilities & Available in 7 housing estates \\
Purpose -built Educational facilities for Children & Present in 2 housing estates \\
Recreational/ Sporting facilities & Non-existence in all 9 housing estates \\
Purpose- built Play Ground for Children & Available only in 1 housing estate \\
Parking Spaces & Available in all 9 housing estates \\
Open Spaces and Green Areas & Present in only 2 housing estates \\
Medical and Health care facilities & Available in only 1 housing estate \\
Condition of access roads & Only 2 housing states have asphalt paved access roads \\
Perimeter fence on the estate & 2 housing estates have perimeter fencing \\
Street Lights in the estate & Available in all 9 housing estates \\
Places of worship within the estate & Available in 7 housing estates \\
Functional Storm water drainage facilities & Available in 5 housing estates \\
Availability of refuse collection bins & Available in only 2 of the estates \\
Public Power Supply & Available in all 9 housing estates \\
Public Water Supply & 4 housing estate are connected to public water supply system \\
\hline
\end{tabular}

Source: Authors' Field Work (2010)

\subsection{Affordability of housing in the estates}

The residents were also asked to rate the affordability of cost of acquiring and/ or renting their dwelling units in the 
estates. The result as shown in Table 5 reveals that around $92 \%$ of the respondents across all income groups indicated that the cost of acquiring or renting their dwelling units was affordable. Specifically, the highest proportion of those who felt that the cost of housing was affordable were the middle-income earners with around $96 \%$ of them saying that the housing was affordability, followed by $94 \%$ of middle-low income and $93 \%$ of high-income earners, respectively. This result clearly shows that residents of the public housing sampled perceived the cost of housing to be affordable.

Table 5: Perception of affordability of the cost of Housing

\begin{tabular}{lcccccc}
\hline Income Groups & \multicolumn{1}{l}{ No Response Highly Unaffordable Unaffordable Affordable Highly Affordable } & Total \\
\hline Undisclosed Income & $0(0.0)$ & $0(0.0)$ & $4(0.8)$ & $30(5.8)$ & $2(0.0)$ & $36(7.0)$ \\
Low-Income & $2(0.37)$ & $3(0.6)$ & $16(3.1)$ & $109(21.2)$ & $7(1.4)$ & $137(26.5)$ \\
Middle Low-income & $0(0.0)$ & $1(0.2)$ & $10(1.9)$ & $170(32.9)$ & $5(9.7)$ & $186(36.0)$ \\
Middle High -income & $0(0.0)$ & $0(0.0)$ & $3(0.6)$ & $73(14.1)$ & $1(0.2)$ & $77(14.9)$ \\
High-Income & $2(0.37)$ & $2(0.4)$ & $2(0.5)$ & $75(14.5)$ & $0(0.0)$ & $81(15.7)$ \\
\hline Total & $4(0.8)$ & $6(1.3)$ & $35(6.8)$ & $457(88.4)$ & $15(2.9)$ & $517(100.0)$ \\
\hline
\end{tabular}

Source: Authors' Field Work (2010)

\section{Discussion}

As noted in the introduction, two research questions related to the characteristics of public housing provided in the study area between 2003 and 2010; and the extent to which these characteristics align with sustainable housing initiative were stated in this study. Based on the findings as presented in the previous section, two major issues related to these research questions were identified and brought forward for further discussion in this section of the paper.

From the result, it is evident that the majority of housing units sampled were single- family walk-in homes of 3bedrooms. This is an indication that this housing type is the most demanded by home seekers in the study area. Also the architectural forms and internal space arrangements of the houses suggest that there was a deliberate attempt to make the houses respond to site and climatic conditions of the area and promote privacy of the residents; hence a majority of the respondents were happy with these aspects of their dwelling units. Based on evidence in the literature indicating that conformity of building forms to site condition (Ghani, 2012); design for good thermal and visual comfort (Abdellatif and Othman, 2006; Winston, 2007; Ibem and Azuh, 2011) are some of the features of sustainable housing development; the housing projects sampled can be considered to be sustainable.

Contrary to the above, a majority of the respondents asked for more spaces in their dwelling units. The desired amenities were mainly guests' rooms, toilets and space for shops. The result specifically reveals that the highest proportion of those who desired guest facilities were middle-low-income earners; and low-income earners had the highest proportion of those who requested for shops in their dwelling units. This suggests that a majority of residents mainly lowincome earners encountered in the survey perceived their residences to be spatially inadequate. Going by the result showing average room occupancy rate in the dwelling units to be less than one person per room, the demand for additional rooms by some of the residents seems odd and may raise a question on the efficiency and sustainability of public housing delivery in the study area. However, when viewed from the perspective of the whole idea of public housing in Nigeria as enunciated in the National Housing Policy (2012), it seems obvious that guest facilities are not necessarily key components of public housing in this country; hence, this can be seen as a reflection of the insatiable desire by man. Viewed from the perspective of the culture of Nigerians that allows urban residents to host relatives and friends who are job seekers and holidays makers on a regular basis; it can be argued that the desire for more sleeping space was to enhance the capacity of the residents to play this role effectively. Similarly, the fact that most of the low income people lived in one-bedroom apartments and had family size of four persons and above could have also contributed to influencing their desire for more sleeping spaces in their homes.

Further, the desire to have space for shops, is quite understandable going by the fact that a majority of the housing estates sampled were actually targeted at low and middle-income earners who may have to operate home-based enterprises (HBEs) as a way of improving the economic status of their families. Generally speaking, it may be argued that inclusion of these additional amenities desired by the respondents can increase the cost of the dwelling units. However, their non-inclusion can result to unplanned transformations of housing units and the estates as a recent study by Aduwo et al. (2013) revealed that in two low-income public housing estates in Lagos, Nigeria, housing transformations were motivated by the desire to add more bedrooms and space for income generating activities. Therefore, based on this 
result, the housing units and estates can be considered to be spatially inadequate; and thus lack sustainable features

Regarding the use of materials, the result shows that there is a predominant use of materials derived from cement, glass, aluminium, and asbestos-based products. This is probably because of the availability, durability and cost of these materials coupled with the availability of skilled labour to handle them. Notably, a majority of the residents encountered in the survey expressed satisfaction with the use of these materials. On this note, the use of readily available and durable materials is considered as another sustainability feature of public housing projects in the study area. However, the predominant use of cement-based materials such as concrete and Sandcrete blocks which contribute to carbon emission and asbestos-based ceiling materials that have health implications (see Whysner et al., 1994) is considered as having negative implications for social and environmental sustainability of the housing projects. Also the use of steel doors; burglary proof windows; and perimeter fences identified as a common feature in the housing estates can be viewed principally as a measure for ensuring adequate security of lives and property; and privacy in the residences. Therefore, going by the submissions by previous authors (Mitlin and Satterthwaite, 1996; Blair et al., 2004; Lutzkendorf and Lorenz, 2005; Ibem and Azuh, 2011) on the need for security of lives and property in housing, this is also considered as another important sustainability feature of government constructed housing in the study area.

In support of previous studies (Jiboye, 2009 and Ibem, 2013), the finding shows that most of the housing estates were deficient in the provision of recreational, educational, healthcare and domestic waste collection facilities. This suggests that adequate consideration is not given to the location of the public housing projects in terms of access to basic urban infrastructure and services. Consequently, only around $13 \%$ of the respondents expressed satisfaction with the closeness of their homes to these amenities and related urban services. In view of the fact that the existing studies (Mitlin and Satterthwaite, 1996; Apparicio and Seguin, 2006; Turcotte and Geiser, 2010; Ibem and Azuh, 2011) have identified access to basic social amenities and infrastructural facilities by residents as one of the key factors that contribute to sustainable development, the housing projects sampled are considered not to be self-sustaining; and are thus not socially and environmentally sustainable.

On economic sustainability of the projects, although public housing in the study area is viewed as profit making venture as explained in the Ogun State Regional Development Strategy (2008), most of the respondents felt that the cost of housing was affordable to them. This result contradicts the findings of previous studies (Mbamali and Okoli, 2002; Oruwari, 2006; UN-HABITAT, 2006) indicating that public housing has not really been seen as affordable to the target population in Nigeria. One possible explanation for this result is that the provision of starter/core houses on mortgage basis for low- and middle-income public sector workers by the developers could have influenced the result on affordability in this study. Therefore, in terms of housing affordability, the housing projects can be considered to be sustainable. This assertion is based on previous studies (Blair et al., 2004; Winston, 2007; Odebiyi, 2010; Pullen et al., 2010; Turcotte and Geiser, 2010; Ibem and Azuh, 2011) indicating that affordability of housing products and services to the target population is a major component of economic sustainability of housing schemes.

\section{Conclusions and Recommendations}

This study examined and analyzed the physical and economic characteristics of public housing constructed between 2003 and 2010 in Ogun State, Nigeria, and the extent to which these characteristics align with sustainable housing initiatives. Based on the findings, the following conclusions are made. The first conclusion is that public housing constructed in the study area in the period under review are mainly walk-in single family units of compact plans and regular architectural forms, constructed with conventional and easy to maintain materials. The second one is that the housing projects are sustainable in terms of affordability; building forms response to site and climatic conditions; and are unsustainable in the use of asbestos-based materials; inadequate provision sleeping spaces and basic social infrastructure for the residents.

In the light of these findings, the following recommendations are made. First is that in order to enhance the sustainability of public housing projects, housing policy makers and developers need to take cognizance of the diverse use of domestic spaces by residents in the formulation of housing policies and design of housing schemes. Second is that, public housing developers should explore the use of alternative building materials that are environmental friendly and promote healthy living conditions. Lastly, there is also a need for the evolution of innovative approaches to improving access to basic social amenities and infrastructural facilities by residents in public housing. Due to the cost implication for providing social infrastructural services in each housing estate, public housing providers can adopt the strategy of providing more centralized facilities for several housing estates.

Although the study has shown the aspects of sustainability public housing developers in Ogun State, Nigeria, are paying much attention to, the current study is limited in a number of ways. First is that it is focused only on public housing 
constructed between 2003 and 2010 leaving out those constructed before 2003 and after 2010. Consequently, the findings cannot be generalised for all public housing in the study area. Secondly, the study is also limited by focusing only on the physical and economic characteristics of housing units and the estates where they are located. Other study can explore other aspects such as energy efficiency of the dwelling units and the implications of the building or estate design on occupants' behaviour.

\section{References}

Abdellatif, M.A and Othman and A.A.E (2006). Improving the Sustainability of Low-Income Housing Projects: The case of Residential Buildings in Musaffah Commercial City, Abu Dhabi. Emirates Journal for Engineering Research, 11(2)47-58

Aduwo, E.B.; Ibem E.O. and Opoko, A.P. (2013). Residents' Transformation of Dwelling Unit in Public Housing Estates in Lagos, Nigeria: Implications for Policy and Practice, International Journal of Education and Research 1(4), 5-20

Blair, J., Prasad, D., Judd, B., Zehner, R., Soebarto, V. and Hyde, R. (2004). Affordability and sustainability outcomes: A Triple - Bottom - Line Assessment of traditional and master Planed communities, Volume 1, Final Report, AHURI, UNSW- UWS Research Centre

Bebbington, J., Brown, J., and Frame, B. (2007). Accounting Technologies and Sustainability Assessment models. Ecological Economics, 61 (2-3); 224-236.

Bonnefoy, X. (2007) Inadequate Housing and Health: and Overview. International Journal Environment and Pollution 30(3/4) 411-429

Chiu, R.L.H. (2000).Environmental sustainability of Hong Kong's housing system and the Housing process model. International Planning Studies, 5(1) 45-64

Chiu, R. L. H. (2003). Social sustainability, sustainable development, and housing, development: The experience of Hong Kong. In R. Forrest and J. Lee (Eds.), Housing and Social Change (pp. 211-238). London: Routledge

Choguill, C. L. (2007). The search for Policies to Support Sustainable Housing. Habitat International, 13(2) 143-149.

Clement, O. I., and Kayode, O. (2012). Public housing provision and user satisfaction in Ondo State, Nigeria. British Journal of Arts and Social Sciences, 8(1), 103-111.

Dalal-Clyton, B, and Sadler, R. (2004). Sustainability Assessment: A review of International Experience and Practice Draft Report for IIED, London

Ekins, P., and Vanner, R.(2007). Sectoral sustainability and sustainability assessment Methodologies: a review of methodology in light of collaboration with the UK oil and gas sector. Journal of Environmental Planning and Management, 50 (1); 87-111

Franks, T.R., (2006). Sustaining Projects Benefits: Masters Course Manual.University of Bradford, UK, Centre for International Development.

Ghani, F.(2012). Issues in Sustainable Architecture and Possible Solutions. International Journal of Civil \& Environmental Engineering IJCEE-IJENS 12(1); 21-24

Hacking, T., and Guthrie, P.(2008). A framework for clarifying the meaning of triple bottom- line, integrated, and sustain- ability assessment. Environmental Impact Assessment Review, 28 (2-3); 73-89.

Hashim, A.H. (2004) Residential Satisfaction and Social Integration in Public Low Cost Housing in Malaysia. Pertanika Journal of Social Science and Humanity 11(1) 1-10.

Ibem, E.O. and Azuh, D.E. (2011). Framework for Evaluating the Sustainability of Public Housing Programmes in Developing Countries. Journal of Sustainable Development and Environmental Protection (JSDEP). 1(3), 24-39.

Ibem, E.O. (2012). Residents' Perception of the Quality of Public Housing in Urban Areas in Ogun State, Nigeria. International Journal of Quality and Reliability Management, 29(9), 1000-1018

Ibem, E.O. (2013). Accessibility to Services and Facilities for Residents of Public Housing in Urban Areas of Ogun State, Nigeria. Urban Forum, 24 (3), 407-423.

Ibem, E.O. and Amole, D. (2013) Residential Satisfaction in Public Core Housing in Abeokuta, Ogun State, Nigeria. Journal of Social Research, 113 (1), 563-581

Ibem, E.O., Opoko, A.P; Adeboye, A.B. \& Amole, D., (2013) Performance Evaluation of Residential Buildings in Public Housing Estates in Ogun State, Nigeria: Users' Satisfaction Perspective, Frontiers of Architectural Research, 2 (2013), 175-190.

Ihuah, P.W, Kakulu, I.I and Eaton, D.(2014).A review of Critical Project Management Success Factors (CPMSF)for sustainable social housing in Nigeria. International Journal of Sustainable Built Environment, 3:62-71

llesanmi, A.O. (2005). An Evaluation of Selected Public Housing Schemes of Lagos State Development and Property Corporation, Lagos Nigeria. Unpublished PhD Thesis Submitted to the School of Postgraduate Studies, Obafemi Awolowo University (OAU) Ile-Ife, Nigeria

Jiboye, A.D. (2009) Evaluating Tenant's satisfaction with Public Housing in Lagos, Nigeria" Town Planning and Architecture 33(4) 239247.

Kain, J.-H., and So "derberg, H. (2008). Management of complex knowledge in planning for Sustainable development: the use of multicriteria decision aids. Environmental Impact Assessment Review, 28, 7-21.

Lee, E., and Park, N. (2010). Housing satisfaction and quality of life among temporary residents in the United States. Housing and Society, 37(1), 43-67

Lutzkendorf, T., Lorenz, D., 2005. Sustainable property investment: valuing sustainable buildings through property performance assessment. J. Building Res. Inf. 33 (3), 212-234 
Mbamali, I. and Okoli, O.G (2002) Affordable Housing for Low Income Group in Nigeria: A Redefinition of the basic Parameters. Housing Today- A Journal of the Association of Housing Corporations of Nigeria 1(5)15-21

Menzies, G.F., Wherrette, J.R., 2005. Windows in the workplace: examining issues of environmental sustainability and occupant comfort in the selection of multi-glazed windows. Energy and Buildings 37 (11), 623-630.

Mitterer, C., Kunzel, H.M., Herkel, S., Holm, A. (2012). Optimizing energy efficiency and occupant comfort with climate specific design of the building. Frontiers of Architectural Research 1, 229-235.

Mitlin, D. and Satterthwaite, D. (1996) "Sustainable development and cities" C. Pugh (ed.) Sustainability, the Environment and Urbanization, London pp.23 - 62, Earthscan Publications Limited

National Housing Policy (2012).Federal Government of Nigeria: Abuja

Odebiyi, S.O.(2010). Sustainable Housing Development in Africa: Nigerian Perspective. International Business and Management, .1 (1) $22-30$

Ogun State Regional Development Strategy. (2008). Our collective responsibility. Ikeja: Comprehensive Project Management Services Limited.

Omole, F.K. (2001) Basic Issues in Housing Development, Ondo: FemoBless Publishers

Ornstein, S.H. (2005) Post Occupancy Evaluation in Brazil, Evaluating Quality in Educational Facilities, School of Architecture and Urbanism, University of Sao Paulo, Brazil.

Oruwari, Y. (2006) Lest We Forget: The Poor People Need Housing in the Urban Areas in Nigeria too-A reflection of Low-income housing provision in A.I. Okewole et al (Eds.) The Built Environment: Innovation Policy and Sustainable Development. OtaNigeria: Department of Architecture, Covenant University, Pp 2-9.,

Pullen, S., Arman, M.,Zillante, G., Zuo, J., Chileshe, N. and Wilson, L (2010).Developing an assessment framework for affordable and sustainable housing. Australasian Journal of Construction Economics and Building, 10(1/2); 48-64

Rotmans, J. (2006).Tools for Integrated Sustainability Assessment: A two-track approach. The Integrated Assessment Journal: Bridging Science and Policy, 6(4); 35-57

Sadler, B.(1999). A framework for environmental sustainability assessment and assurance. In: J. Petts, ed. Handbook of environmental impact assessment. Oxford: Blackwell, 12-32.

Savaya, R., Spiro, R. and Elran-Barak, R. (2008) Sustainability of Social Programs: A Comparative Case Study Analysis, American Journal of Evaluation 29 (4) 478-493

Turcotte, David and Geiser, Ken (2010). A Framework to Guide Sustainable Housing. Housing and Society . 37(2)87-117

UN-HABITAT (2006). National Trends in Housing -Production Practices Volume 4: Nigeria, United Nations Centre for Human Settlements: Nairobi

VROM (Ministry of Housing, Spatial Planning and Environment, 2005).The 2005 Sustainable Refurbishment of High-Rise Residential Buildings and of Surrounding Areas in Europe. Report of European Housing Ministry held in Czech Republic: Prague, March

World Commission on Environment and Development (1987), Our Common Future, the Report of the Brundtland Commission, Oxford University Press, Oxford.

Whysner, J.; Covello,V.T.; Kuscherner,M.; Rifkind, A.B.; Rozman, K.K.; Trichopoulos, D. and Williams, G.M.( 1994). Asbestos in the air of Public Buildings: A Public health risk? Preventive Medicine, 23(1), 119-125.

Zami, M.S. and Lee, A. (2010) Misunderstanding of Housing and its Influence on the Success of Low Cost Housing Projects-State of the Art Review. The Built \& Human Environment Review, 3:1-11. 